\title{
Access and Use of Digital Technologies in Early Childhood: A Review of Mixed Messages in Popular Media
}

\author{
LAURA TEICHERT \\ Western Michigan University \\ ANN ANDERSON \\ University of British Columbia \\ JIM ANDERSON \\ University of British Columbia \\ JAN HARE \\ University of British Columbia \\ MARIANNE MCTAVISH \\ University of British Columbia
}

\begin{abstract}
This paper reports on an analysis of 60 print and online articles collected in a metropolitan area in Canada that describe children's digital engagement through a focus on 'early literacy' or 'digital literacy'. Findings reveal mixed messages about children's use of digital technology that create competing frames for adults supporting (or not) young children's digital literacy practices. Digital technology was often characterized as something to limit/control, except in school, where digital literacy was characterized as holding a proper place when controlled by educators. Consistent across media messaging was the promotion of traditional, print-based texts as an essential early literacy practice.
\end{abstract}

Keywords

early digital literacy; early literacy; screen time

Many children lead media rich lives literally from birth (Gillen et al., 2018) as they are encouraged to use digital technology and to develop digital skills (Kervin et al., 2018; Marsh et al., 2017; Ozturk \& Ohi, 2019). This uptick of use among children under fiveyears of age has led to an increase in scholarly interest and debate about the effects of "screen time" on learning and development. Multiple disciplines have taken up this investigation (i.e., education, social policy, childhood studies, psychology, child development, etc.) but have not always coexisted harmoniously (Livingstone, 2016). Scholars coming largely from qualitative epistemologies have highlighted the positive learning experiences that can arise when using digital technology. Other scholars have tended to focus on causal effects that construct explanations for "complex real-world conditions that give rise to harms or benefits" of digital technology (Livingstone, 2016, p. 9) more narrowly. Meanwhile, these debates between experts about the risks or 
opportunities of children's digital technology use are played out publicly in popular media. Parents and caregivers are told to 'keep up' with digital technology to ensure children's future successes (Livingstone \& Franklin, 2018) while simultaneously being told digital technology might be harmful.

Central to the debate is the notion of 'screen time' - the amount someone interacts with a screen (e.g., computer, phone or tablet, television, video game) in a given time frame (Orben, 2020). The increasing sophistication of modern digital technology and the diverse array of applications digital devices now perform (e.g., smartphones and tablets) presented a need to conceptualize behaviour under a common term. Hence, the umbrella term 'screen time' proved helpful in expressing concerns on the part of some people about an increasingly digital world (Orben, 2020). Influential organizations, such as the American Academy of Pediatrics ([AAP] 2011, 2016) and the Canadian Paediatric Society (2018) urged parents and caregivers to limit or restrict the screen time of children under the age of five years. Children between two and five years were recommended no more than one-hour of daily screen time while those under 24 months were recommended no screen time.

However, as Livingstone and Blum-Ross (2020) argue, the umbrella concept of screen time overshadows important contextual considerations such as "what (the content), how, where, when (the context), why, and with whom (the connections) children are watching, playing, and doing things with media, along with people's judgments and values regarding these activities" (p. 56). Therefore, screen time is helpful for articulating caution and concern, yet it also fails to recognize the potential benefits young children gain when interacting with screens in their daily lives.

As researchers interested in families' literacy practices in the home and community, the inclusion of digital literacy has become a larger focus of our collective work. Recently, with the COVID-19 pandemic, these interests have been amplified as early learning settings were disrupted and digital technologies became increasingly more important in daily life. It is within this context that we frame this paper.

The term digital literacy has many definitions (Burnett, 2009). We conceptualize digital literacy as being bound by social, cultural and ideological contexts. People become digitally literate by interacting with other members of their community and using relevant digital devices (or digital tools) within digital networks. Operational skills are necessary in order to successfully use a variety of digital tools (e.g., computer, iPad, streaming TV, or smartphone), navigate networked screens (e.g., Cloud technologies) and use social media (e.g., Facebook). Yet, digital literacy encompasses more than a list of skills associated with operating digital technology. It includes a mindset to negotiate meaning from a variety of digital contexts. As an example, a digitally literate person may be able to log in and access social media (i.e., operational skill) while also understanding the social contexts of their voice within specific media spaces and across media spaces (e.g., personal, business, or professional uses of Twitter). We use the term 'digital technology' to categorize electronic and computerized technology composed of data in the form of binary digits. Digital technology is a broad term for the multitude of media and devices that are used for communication, entertainment and gaming.

We were struck by the polarized perspectives in the research literature on young children's digital tool use (e.g., Madigan et al., 2019; Orben, 2020). As such, we sought to examine how research findings and policy statements were taken up in news media and on 
organizational websites in Vancouver, a multicultural metropolitan area of Canada. Therefore, we examined the narratives or messages that online and print media created when describing children's digital engagement. Furthermore, we were interested in the congruency between the explicit and implicit messages in the images and in the text as they related to "literacy", as well as to "digital".

Through a lens of critical discourse analysis (e.g., Fairclough, 2013; Gee, 2014), in this paper we explore the narratives that online and print media created when describing children's digital engagement. The following research questions guided our work:

1. How is literacy or early literacy defined in online and traditional newspaper publications?

2. What images are used to depict literacy in media publications?

3. How is young children's digital technology use framed in these publications?

4. What is the overall message these definitions and views convey?

Our analysis provides evidence of how two discourses in news media and on provincial websites operated in the same time period, thereby creating mixed messages about the role of digital technology in children's lives.

\section{Background}

Research on young children and digital tools can be categorized as falling into two camps: those advocating for, and supporting children's digital engagement and those advocating that children's screen time be strictly limited and controlled. Ultimately, parents' and caregivers' attitudes and beliefs influence the decisions of what tools they make available to children in their homes and communities. However, these beliefs are informed and shaped by the ideologies and messages in circulation in the society in which they live, what Bronfenbrenner (2005) called the macro system.

\section{Digital Literacy in Young Childhood}

For almost 20 years, researchers have observed and documented the use of digital technology in the lives of young children (e.g., Marsh 2004; Marsh et al., 2017; Plowman et al., 2008; Plowman \& McPake, 2013; Wohlwend, 2009, 2013, 2017). These largely qualitative studies have shown that digital technology can provide young children with opportunities to: engage in relevant communicative practices before being able to read and write conventionally (McPake et al., 2013); extend their knowledge and understanding of the world (Davidson, 2009); develop "cultural awareness" (Plowman et al., 2008, p. 309); and, understand the roles of digital technology in everyday life (Kervin et al., 2018; Livingstone \& Blum-Ross, 2020; McPake et al., 2013; Wong, 2015).

Young children draw from their experiences with, and knowledge of, digital technology in their play activities, such as dressing up like favored characters, or reenacting scenes from their favourite TV and movie programs (Huh, 2015); using discarded mobile phones or laptops as props during imaginative play (Wohlwend, 2013); or incorporating digital tools into their offline play activities (e.g., bringing a tablet inside a pillow fort) (Marsh et al., 2015). Although sometimes favoring digital technology for entertainment, children continue to engage with traditional toys and enjoy outdoor activities (Gillen et al., 2018; Stephen et al., 2008; Teichert \& Anderson, 2014). Virtual worlds resemble offline play (e.g., dressing up avatars) and they afford peers opportunities 
to play together during times they otherwise could not (Shapiro, 2018; Wohlwend et al., 2011). Scholars who support children's early digital use focus on the benefits of these tools in young children's development and learning and urge that digital play be recognized and valued in the same way as traditional play (Edwards, 2013; Marsh et al., 2016). For example, Marsh et al. (2016) adapted Hughes' (2002) definitions of play-type to reflect contemporary children's digital realities and define digital play. Hughes, for instance, drew from Vygotsky (1972), when describing symbolic play as, "when children use an object to stand for another object, [and for example] a stick becomes a horse" (p. 246). Marsh et al. extended this definition into the digital sphere by defining symbolic play as, "when children use a virtual object to stand for another object [and for example] an avatar's shoe becomes a wand" (p. 246). In total, Marsh et al. redefined 16 types of play to include digital activities.

Researchers such as those just cited, describe benefits for young children engaging with digital technology. However, much of this research entailed smaller, qualitative studies that cannot be generalized to wider populations or the findings come from selfreported survey data. As well, much of this work has been conducted with white, middleclass families. While it is an emerging area of study (Livingstone \& Blum-Ross, 2020), not enough data is yet available on the roles of digital technology in the lives of multicultural families.

\section{Limiting Screen Time}

Conversely, scholars concerned about young children's digital engagement emphasize children's need for social interaction and hands-on exploration, and generally discourage access to digital technology in early childhood. They argue that too much digital engagement can negatively impact children's health, cognitive development, and learning (e.g., AAP, 2016; World Health Organization, 2019) and have suggested digital technology (and media more generally) make children "passive learners and take away from more active, worthwhile activities" (Razfar \&Yang, 2010, p. 120). The amount of time spent watching screens is frequently cited as contributing to the following problems: rising obesity rates among children (AAP, 2016); reduced sleep (Hale \& Guan, 2015; Cheung et al., 2017); aggressive behaviour (AAP, 2011); attention deficits (Christakis et al., 2004; Miller et al., 2007); and language and cognitive delays (AAP, 2016; Courage, 2017). Madigan et al. (2019) found that children aged 24 months and 36 months with higher levels of screen exposure had poorer performance on assessments for developmental milestones at 36 and 60 months than children with less screen exposure.

With respect to potential cognitive delays, the AAP identified possible negative development of 'executive functioning' and "transfer deficit" (Barr, 2013, p. 206) as concerning. Executive functions manage self-regulation and some research has indicated a relation between early screen exposure and poorer executive functioning (see Courage, 2017 for a detailed analysis). However, causation has yet to be determined as researchers cannot determine whether young children with more challenging temperaments watch screen media as a calming mechanism, or if it is the screens that create these temperaments (Courage, 2017). Transfer deficit, which is the ability to transfer understanding from one context to another, has also been identified as an issue in children's use of digital technology. For example, Radesky and Zuckerman (2017) found that children could imitate 
what they saw on screen, but it was limited. They found children had difficulty transferring the knowledge gained from two-dimensional screen media to their three-dimensional experiences (i.e., giraffe on a TV is not easily transferred to understanding a giraffe at the zoo).

However, critics of the research on screen effects noted that studies warning of the negative effects of digital technology use between birth and five-years found small or no effects and argued the concerns were overstated (e.g., Viner et al., 2019 for the Royal College of Paediatrics and Child Health, UK). Przybylski and Weinstein (2019) conducted telephone interviews with 20,000 caregivers in the United Kingdom who cared for children between the ages of two and five years. Their findings suggested there was little or no support on the part of respondents for the claim that there are harmful links between digital screen use and young children's psychological well-being. They explained that their study "informs an existing literature with older children and adolescents which finds mixed support for the links between screen use and wellbeing, with some studies showing harmful effects and others showing negligibly small and non-significant correlations indicating harm" (p. 61). Orben (2020), in her narrative review of 82 systematic reviews and metaanalyses, concluded there was a lack of clear cut or concrete evidence for a "link between digital technology use and well-being" (p. 407). She indicated that there is a dearth of high-quality research in the field, which has resulted in "the production of much conflicting evidence" (p. 412).

Others have argued that effects-based research has focused on TV or computer screen viewing and that these findings cannot be transferred to touchscreens such as smart phones and tablets. Cheung (2016) concluded that:

The problem is that touchscreens are not the same as TV or computers; they combine both elements of passive entertainment of TV and interactivity of videogames. Active interaction with touchscreens can generate dynamic stimulation, and, if used appropriately, may be just as engaging and cognitively stimulating as traditional toys or books (n.p.).

Some researchers have found positive effects for toddlers' use of screens. For example, Strouse and Ganea (2017) noted an increase in attention and positive affect when reading electronic books compared to printed books. Likewise, Bedford et al. (2016) noted a positive association between active scrolling on a touchscreen and fine motor skills (e.g., stacking blocks, pincer grip) and did not find evidence of a negative association between infants' first use of a touchscreen and later developmental milestones.

\section{Parents'/Caregivers' Attitudes and Beliefs}

As this brief review demonstrates, the research on young children's use of digital technology is contradictory with some studies highlighting positive effect, others the opposite. Yet, it is parents and caregivers, who are left to make sense of the competing claims made by researchers as they are reported in news outlets, on the websites of agencies and organizations, and on social media. Some parents and caregivers believe that children's use of digital technology is good and contributes to brain development (Vittrup, Snider, Rose \& Rippy, 2014). Parents and caregivers have also described how they believed digital technology contributed to children's learning and development and that it is a necessary tool in today's society and prepares children for the future work force (Dias et al., 2016; 
Gillen et al., 2018; Schlembach \& Johnson, 2014, Vittrup et al., 2014). For example, the parents who Aubrey and Dahl (2014) interviewed believed that digital technology helped their children develop basic skills, like letter, number and colour recognition. Other studies described parents and caregivers who actively scaffold their children's digital technology use by modeling how to use devices, giving direct instructions, explaining how to use digital devices, and praising children's uses (Gillen et al., 2018; Kervin et al., 2018; Kumpulainen et al., 2020; Ozturk \& Ohi, 2019; Plowman \& McPake, 2013; Stephens et al., 2013).

However, other studies have documented that some parents and caregivers are apprehensive about the effects of screen time on children's overall development (O'Hara, 2011; Stephen et al., 2013; Teichert, 2017). This belief led these adults to limit children's access to digital technology and direct their children to engage in more traditional childhood activities, such as drawing or outdoor play (Dias et al., 2016; Teichert, 2017; Wolfe \& Flewitt, 2010). Kucirkova et al. (2018) found parents were more concerned about boys' digital engagement and the possible ill health effects of digital technology than they were about girls.

Yet, not all research has depicted families as either for digital technology or against it. Plowman et al. (2012), in their study involving 14 families, described parents' beliefs about digital literacy practices on a spectrum. Parents fell anywhere between negative views, ambivalent views, and positive views. Families' uptake of digital tools reflected more their beliefs than it did their socioeconomic status. Livingstone and Blum-Ross (2020) also noted parents' attitudes towards children's use of digital technology fell on a spectrum. Importantly, though, their recent work highlighted the nuanced ways that families negotiated digital technology use in their homes. They described some parents who were ambivalent, others against digital technology, and some for digital technology; these positions were constantly shifting and reshaping. Parents in the same home may at times differ in their values and beliefs and negotiate with each other on what the best approach may be for their children. For example, Livingstone and Blum-Ross (2020) demonstrated this tension when describing participants Lara and Pawel Mazur. Lara believed digital technology provided their six-year old son with opportunities to "build his confidence and make him independent" (p. 1) while Pawel was cautious and worried about online risks, "especially after [son's friend] introduced him to a violent video game" (p.1). Pawel therefore set passwords on all devices in an attempt to monitor and control his son's access.

News media reports tend to alternate between the damaging effects of screens on family relationships and advocating for the potential of screens to help families stay connected. Readers and viewers are left "fearful or hopeful, and oftentimes just plain confused" (Gee et al., 2018, p. 2) about how to navigate a complex technological world. This situation may lead parents to feel guilty about the decisions they make and uneasy about how to 'do right' for their children (Livingstone \& Blum-Ross, 2016, 2020; Teichert, 2017, 2020). 


\section{Theoretical Framework}

\section{Bronfennbrenner's Bio-Ecological Theory}

This study is informed by Bronfenbrenner's (2005) bio-ecological theory that posits that children's development and learning are influenced by different systems or spheres. The microsystem, consisting of family, neighbors and teachers, most directly influences development and learning. However, the macrosystem - the "belief systems, resources, hazards, lifestyles, opportunity structures, life course options and patterns of social change..." (p. 149) of the larger society - also affects development and learning. For example, in an individual child's microsystem, their access to digital tools, the parents'/ guardians' beliefs about the role of digital technology in their child's development and learning, and their own engagement with and use of technology, their interactions with peers in their community, the families' socio-economic status, and their exposure to digital tools at school or in the early childhood center, influence the role (if any) that digital technology plays in their development and learning. Likewise, at the macro-level, the policies of governments and educational authorities, institutions' and organizations' perspectives about the role of digital technology in young children's lives, and dominant ideologies about the issue held by the wider society indirectly influence the child's microsystem. In terms of this study, the messages about young children's digital tool use conveyed by popular media and represented on organizations' websites constitute part of the macrosystem of children living within the geographical area where the study took place, and according to bioecological theory, potentially affects young children's development and learning, particularly in terms of digital technology.

\section{Critical Media Theory}

In contemporary western societies, the media are an important part of the macrostructure, as they hold significant power in shaping the meanings that people construct and the realities that they experience (e.g., McLuhan, 1964). As Kellner and Share (2019) point out, "all cultural texts have distinct biases, interests, and embedded values, reproducing the point of view of their producers and often the values of the dominant social groups" (p. 17). Furthermore, they posit, "Media culture shapes our views of the world into categories of "us" and "them," influencing our deepest values: what we consider good or bad, positive or negative, moral or evil" (p. xi). McLuhan wrote during the analog age of media communication, while today society interacts with a multitude of digital platforms. At their base, platforms are the infrastructure on which applications (apps) are built; however, on a social level, they are also spaces that facilitate social and economic exchange (Gillespie, 2010; Nichols \& LeBlanc, 2020). Srnicek (2017) used the term 'platform societies' to frame the social, technical, and economic relations between people and platforms. Most relevant to our study is the social aspect of platforms and how people integrate apps into their daily lives and how these apps interact with each other and the media messages derived from these platforms. Theorists posit platforms create "new value regimes and economies" (Helm \& Seubert, 2020, p. 187) as powerful platforms (e.g., Google, Apple, Amazon, Facebook, and Microsoft) set terms for how people interact and communicate with one another (van Dijck et al., 2018). Given this influence and the fact that parents and caregivers hold varying perspectives of the roles that digital technology 
should or should not play in early childhood (e.g., Teichert, 2018), it is important to examine the messages contained in media.

\section{Methodology}

This study is part of a larger study investigating the digital literacy practices of families with young children in their homes and communities. With respect to this paper, we examined the narratives that online and print media created when describing children's digital engagement. Furthermore, we were interested in the congruency between the explicit and implicit messages in the images and in the texts as they related to "literacy" as well as "digital".

The authors are educators and researchers with an interest in, and focus on, early childhood literacies. We are also committed to working toward greater access, equity and inclusivity in terms of educational, economic and socio-political opportunity for children and families who live on the margins of society. In terms of digital technology and digital literacy, we are concerned with the digital divide (van Dijk, 2000) as well as the conflicting messages presented by popular media and organizational websites whose intended audience include parents and caregivers of young children, about the role of digital technology during the early childhood years.

\section{Data Collection}

The data are drawn from two rounds of online and print media scans. All materials collected were contained by geography (i.e., publications accessible in the focal neighborhood in Vancouver) and by time.

Vancouver was an appropriate site for this study, for several reasons, in addition to the pragmatic one that, at the time of data collection, the authors worked or studied and lived there. The city had a number of newspapers that were freely and widely distributed in neighborhoods. It is also a culturally and linguistically diverse city with many new immigrant and refugee families, representing varying educational experiences and views about child-rearing, education and learning. The city also has great socio-economic disparities, and one of its neighborhoods is often referred to as the poorest postal code in Canada (Lupick, 2019). As well, since 2001, the province has aimed to be a knowledgebased society, when the Premier of the province at that time established the Premier's Technology Council. The premier's vision for education in the 21 st century partially influenced a revision of the province's K-12 curriculum, a document that encourages the incorporation of digital technology from kindergarten onwards (See Teichert, 2014, for further analysis). In summary then, the city represents the realities of many contemporary metropolitan areas in Canada and elsewhere in an era of increasing movements of people (Vertovec, 2021) in a world becoming more connected through digital technology.

The first collection occurred between August 1, 2016 and September 30, 2016 resulting in 47 articles that focused on either early literacy or digital literacy (and sometimes both). Data came from five newspapers: four available in both online and print formats, three of which were free publications, and one print-only weekly publication. The second round of collection occurred during November 2018, lasting 30 days and yielded 13 articles from five newspapers (four online/print; two free). Table 1 provides a summary of the news media publications collected in both rounds of data collection. As well, we 
reviewed seven pertinent local websites in both rounds of data collection. The websites were selected based on their involvement in educational programing and/or health programing, in the geographical area of the study and included the following: Ministry of Education, local district school board, local district StrongStart (a government supported early childhood initiative), local public library, local public health agency, a local parent program (website available on school board website), and a provincial health strategy website. As noted, parents and caregivers of young children are part of the intended audience of these sites. Data were collected from all seven websites during the 2016 scan; however, only three websites contained content relevant to the study during the 2018 scan. None of the magazines that we reviewed yielded pertinent articles during these scans.

Table 1

Summary of Data Sources

\begin{tabular}{|c|c|c|c|c|c|}
\hline $\begin{array}{l}\text { Newspaper } \\
\text { Name }\end{array}$ & $\begin{array}{c}\text { Scan } \\
\text { publication } \\
\text { collected in }\end{array}$ & $\begin{array}{c}\text { Description (including width } \\
\text { of coverage) }\end{array}$ & $\begin{array}{l}\text { Mediums } \\
\text { available }\end{array}$ & $\begin{array}{l}\text { Publication } \\
\text { frequency }\end{array}$ & Cost \\
\hline $\begin{array}{l}\text { The Globe and } \\
\text { Mail }\end{array}$ & Both & $\begin{array}{l}\text { One of two major national } \\
\text { newspapers in Canada. } \\
\text { Distributed across the country. }\end{array}$ & $\begin{array}{l}\text { Online } \\
\text { and print }\end{array}$ & $\begin{array}{l}\text { Daily Monday- } \\
\text { Saturday }\end{array}$ & Subscription \\
\hline $\begin{array}{l}\text { The National } \\
\text { Post }^{a}\end{array}$ & 2018 only & $\begin{array}{l}\text { One of two major national } \\
\text { newspapers in Canada. } \\
\text { Distributed across the country }\end{array}$ & $\begin{array}{l}\text { Online } \\
\text { and print }\end{array}$ & $\begin{array}{l}\text { Daily Monday- } \\
\text { Saturday }\end{array}$ & Subscription \\
\hline $\begin{array}{l}\text { The Vancouver } \\
\text { Sun }\end{array}$ & Both & $\begin{array}{l}\text { One of two province-wide } \\
\text { newspapers in Vancouver. } \\
\text { Distributed to communities } \\
\text { across the province. }\end{array}$ & $\begin{array}{l}\text { Online } \\
\text { and print }\end{array}$ & $\begin{array}{l}\text { Daily Monday- } \\
\text { Saturday }\end{array}$ & Subscription \\
\hline Metro $^{b}$ & Both & $\begin{array}{l}\text { A chain of newspapers } \\
\text { published in five major cities } \\
\text { across the country. } \\
\text { Publications provide local } \\
\text { editions for each city it is } \\
\text { published in. }\end{array}$ & $\begin{array}{l}\text { Online } \\
\text { and print }\end{array}$ & $\begin{array}{l}\text { Daily Monday- } \\
\text { Friday }\end{array}$ & Free \\
\hline 24 Hours $^{c}$ & 2016 & $\begin{array}{l}\text { A local publication distributed } \\
\text { within the community of study } \\
\text { and its surrounding suburbs. }\end{array}$ & $\begin{array}{l}\text { Online } \\
\text { and print }\end{array}$ & $\begin{array}{l}\text { Daily Monday- } \\
\text { Friday }\end{array}$ & Free \\
\hline $\begin{array}{l}\text { The Vancouver } \\
\text { Courier }\end{array}$ & Both & $\begin{array}{l}\text { A local publication distributed } \\
\text { within the community of study } \\
\text { and its surrounding suburbs. }\end{array}$ & Print & Weekly & Free \\
\hline
\end{tabular}

${ }^{\text {a }}$ This publication was scanned in 2016 but did not yield articles relevant to the study.

${ }^{\mathrm{b}}$ At the time of the study, the publication was still available in print. As of 2019, it is an online-only publication.

${ }^{\mathrm{c}}$ This publication ceased publication prior to the 2018 data collection. 


\section{Data Analysis}

Drawing from Foucault's (1972) discourse theory, we considered what knowledge was promoted, how this knowledge was passed on, what function it held for the "constitution of subjects and the shaping of society" (Jäger, 2001, p. 33); and finally, the impact the knowledge could potentially have in the overall development of society. Our unit of analysis was media content containing text and/or images relevant to "digital technology", "early literacy" or "children's digital engagement." With a critical discourse analysis lens (Fairclough, 1995; Gee, 2014; Kress \& van Leeuwen, 1996) we analyzed the rhetoric of online and print media texts for their discursive, or argumentation strategies (Meyer, 2001), and considered the role of audience. Also informing our analysis was Gee's (2014) notion that language is always ideological or political, and for example, we examined how the texts in our corpus explicitly or implicitly conveyed the message that access to and use of digital technology in early childhood was something to be avoided or to be embraced. We read the texts multiple times in their entirety. We then reread them, highlighting the discourse or language that was used to describe literacy and digital technology. That is, we examined critically the "language associated with a particular field" (Fairclough, 2013, p. 179) (i.e., literacy and digital technology), identifying the explicit and implicit meanings and whether digital technology was portrayed negatively, neutrally or positively. Discourses play a role in shaping social meanings and realities (Mackenzie, 2019). Therefore, we noted not only themes present in our corpus of texts, but considered the information being disseminated by news media and how it might shape parents' and caregivers' beliefs about digital technology, and consequently, their children's access and usage. Codes were created under categories of "negative", "neutral", or "positive" that demonstrated the argumentation strategies used by the author. For example, under the "negative" code, phrases/words like "limit", "detox", or "control" were noted. Table 2 provides an example of this analysis from the "digital technology-negative" code and "digital technology-positive" categories. The bolded text are examples of key rhetoric and argumentation used by the author.

Table 2

Representation of Digital Technology Codes

\begin{tabular}{|c|c|c|c|c|c|c|}
\hline Source & Date & Summary & Key phrases & Sub Code & Image & Digital? \\
\hline Vancouver & Monday & Article reports on & "When I put it & Screen time & & Yes \\
\hline \multirow[t]{12}{*}{ Sun $^{\mathrm{a}}$} & November & Cyber Monday by & all together and & Control & & \\
\hline & 26,2018 & Nature Canada, a & saw the story the & & & \\
\hline & & review of existing & research was & & & \\
\hline & & research on screen & telling, I was & & & \\
\hline & & time. Authors & shocked," & & & \\
\hline & & concluded children & [author] said. & & & \\
\hline & & spend too much & "We all know & & & \\
\hline & & time with screens & kids are & & & \\
\hline & & and should spend & spending too & & & \\
\hline & & more time outside. & much time with & & & \\
\hline & & The quoted author & screens, but the & & & \\
\hline & & weracy & Volume 23, & 202 & & se 115 \\
\hline
\end{tabular}




\begin{tabular}{|c|c|c|c|c|c|c|}
\hline Source & Date & Summary & Key phrases & Sub Code & Image & Digital? \\
\hline & & $\begin{array}{l}\text { suggests parents } \\
\text { limit screen time } \\
\text { and create screen } \\
\text { free zones. }\end{array}$ & $\begin{array}{l}\text { impact of that is } \\
\text { much greater } \\
\text { than I } \\
\text { imagined." }\end{array}$ & & & \\
\hline $\begin{array}{l}\text { The Globe } \\
\text { and Mail }\end{array}$ & $\begin{array}{l}\text { Tuesday } \\
\text { November } \\
27,2018\end{array}$ & $\begin{array}{l}\text { The benefits of } \\
\text { playing Fortnite } \\
\text { with } 10 \text { year old } \\
\text { son (with reference } \\
\text { to similar online } \\
\text { video games) }\end{array}$ & $\begin{array}{l}\text { I relented. His } \\
\text { friends were } \\
\text { playing it, and } \\
\text { they were able } \\
\text { to communicate } \\
\text { via headsets. }\end{array}$ & $\begin{array}{l}\text { Communication } \\
\text { Social digital } \\
\text { tech }\end{array}$ & $\begin{array}{l}\text { Desktop } \\
\text { screen, } \\
\text { Fortnite } \\
\text { on } \\
\text { screen. } \\
\text { Angle: } \\
\text { taken } \\
\text { from } \\
\text { behind } \\
\text { youth. }\end{array}$ & $\begin{array}{l}\text { yes- text } \\
\text { and } \\
\text { image }\end{array}$ \\
\hline
\end{tabular}

Note. All data samples were collected during the second round of collection in 2018.

a This data was drawn from the broader category "digital technology-negative"

b This data was drawn from the broader category "digital technology-positive"

\section{Images}

We drew from Kress and van Leeuwen (1996) to analyze each image and identified: i). who was represented, ii). what they were doing and where, and iii). what literacy(ies) was/were represented, and iv). what digital tools were depicted (if at all). An example of this process comes from an image collected in the 2016 scan. The code was "school-based literacies" and the image accompanied an article outlining tips for parents and caregivers and their children to ensure a smooth transition back to school. The image depicted a mother and son sitting beside each other looking at a print novel. The son held the book while the mother looked over his shoulder. Behind them was a chalkboard with a weekly schedule written on it. It depicted literacy as print-based as no digital tools were present and the implicit message was that reading print books assisted a smooth transition back to school.

\section{Results}

\section{Contradictions in Narrative}

We noted contradictions in how media framed young children's engagement in digital literacy. In both 2016 and 2018, we collected data that described digital technology as beneficial or positive while also finding sources that cautioned about the negative uses of digital technology. For example, in 2016, five newspaper articles encouraged "coding" as a required course for children, including those in the early years. At the same time, eight newspaper publications continued to highlight the need for limited screen time in children's lives. Interestingly, school was cited as a space to promote digital technology, most notably through coding skills, but also in 'back to school' articles that included digital tools as necessary for school success. Four images accompanied articles about school (i.e., 'back to school') that included a digital tool (e.g., student working at a computer). 
However, within the context of using digital technology in schools, contradictions existed. While five articles touted the need for coding and digital technology in elementary school, two articles argued student-owned devices should not be permitted in the classroom (i.e., student-owned mobile phone or tablet). For example, one local newspaper opinion writer suggested this was because "school is a place for learning" and the potential for private, non-school use of digital technology was enough to exclude personal devices. As the writer stated, "it would be impossible for teachers to monitor their students' use."

Contradictions also were present within the same institutional or organizational body. The Ministry of Education website, acknowledging the realities of children's digital worlds and contemporary society, had begun including coding and technology skills in the provincial curriculum, and explicitly "encouraged the use of technology" for all grade levels. Yet, a local school board (that operates under the auspices of the Ministry) promoted print-based reading for kindergarten students and ignored digital texts and devices.

The data collected in two rounds of collection contained two conflicting discourses that operated simultaneously in news media and on provincial websites: digital technology is beneficial and that screen time must be limited and controlled.

\section{Digital Literacy as Beneficial}

In total, 15 newspaper sources were coded for positive messages related to digital technology. Of these sources, seven came from comic strips, two highlighted commercial products, and two were advertisements. These messages generally fell into two categories: skill development and intergenerational bonding.

Skill development. Three articles advocated for coding as a requirement in children's schooling in preparation for future employment. Phrases such as, "In the future, every job will have a technical aspect" (Vancouver Sun, September 2016) and, "By prioritizing coding, Canadian children will be better prepared for the jobs of the future" (The Globe and Mail, August 2016) highlighted the importance of this skill set in newspapers and on the Ministry of Education website. In addition, digital technology skills were framed as important "so that kids understand the way the world around them works". The attention to this digital priority may be a result of where these publications were produced, given that in 2016, the British Columbia Ministry of Education introduced a revised curriculum, championing digital technology and digital literacy as a reflection of 21 st century learning principles.

In 2016, the local 24 Hours newspaper reported on the University of British Columbia's eSports association and its outreach to youth in the community. The emphasis was on dispelling the negative depiction of video-gaming and eSports by highlighting the positive role video games played in overall skill development, such as "use gaming as a basic platform to develop other skills, including project management, marketing, and more". Notably, the association wanted to provide youth "a positive environment to grow in".

Intergenerational bonding. In 2016, Pokémon Go was at the height of its popularity and two comic strips (Betty and Family Circus) published a series related to the virtual app. Both comics depicted an intergenerational aspect to the game and the comradery between 
players. For example, Family Circus depicted a grandmother sitting on a couch while her grandson jumped up and down on the floor. In the first comic panel, he explained the game. In the final panel, the text read, "well, you'd like it Grandma!" The popularity of the game also extended to advertising as Bell Media, a national telecommunications provider, used the game to promote a smartphone and data plan. In total, six data sources referenced Pokémon Go.

In 2018, the game Fortnite had exploded in popularity and the Globe and Mail published an opinion article that described the benefits of the author's 10-year old son playing the game. Phrases used by the author emphasized the social nature of the game, as users could communicate with each other through headsets. The game was framed as a way to build bonds between pre-adolescent children and their parents using phrases such as "could give me a Fortnite lesson", and "... get him started on V-Bucks or his Battle Pass, and there's no stopping him. He can talk for days." Central in the promotion of the video game, however, was the "play together" aspect.

\section{Screen Time Should be Limited and Controlled}

More frequently, however, news media articles cautioned about the use of screens for children. Twelve articles describing the need to limit screen time were collected, eight in 2016 and four in 2018. Of the 12 articles collected, three were published in national newspapers (i.e., Canada-wide circulation). In 2016, the Vancouver Sun published four articles negatively depicting digital technology in a 30 day span. Articles used phrases such as "more green time (and) less screen time" (Vancouver Sun, November 2018) and "sedentary screen time has become an ever-increasing risk for kids" (24 Hours, September 2016) to express concern about children's health. This characterization often led to recommendations that, "screen time [be] limited and closely monitored" (24 Hours, September 2016). One province-wide health initiative (i.e., advocating for 60 minutes of rigorous physical activity daily) directly stated that screen time limited physical activity (www.healthyfamiliesbc.ca). The website page was titled, "Make room for play!" and led with statistics about how much screen time Canadian children engaged in and recommended that children's screen time be limited. The organization advertised how they could provide "you" with skills to turn children's "virtual play into real, active play!" Other phrases described developmental concerns, such as "teach [children] to thrive without depending on their devices" (24 Hours, September 2016) or "Do you every give yourself time to daydream?" (Vancouver Sun, August 2016). In another example, the need to disengage from digital technology was described with the phrases "screen free" and "digital detox" (Globe and Mail, August 2016) and emphasized the need for children to have non-digital spaces.

In contrast to the social benefits arguments for Pokémon Go and Fortnite cited earlier, articles expressed concern about a lack of interaction when children use digital technology. For example, one description stated, "I had some friends come over along with two young kids and their parents sat the five-year-old down with his computer. His games were creative and amazing, but there was no interaction" (Vancouver Courier, September 2016). Other articles highlighted the potential for antisocial behaviour, such as bullying. When describing social interaction online through social media apps, the description was 
negative, for example, "addictive behaviour" (Globe and Mail, August 2016); "addicted to social media" or "preoccupation with peer drama" (Vancouver Sun, September 2016)

One 2016 article was particularly negative in assessing children's digital engagement. The writer suggested parents providing children with cellphones was an example of "over-protective, over-involved parents interacting with their kids throughout the school day ... from chit-chat to getting the latest gossip, to messages about pick-up time and supper." Students' use of digital tools and texts in learning was questioned,

As real books and libraries dwindle in significance in the classroom, following suit with how society in general now goes to social media and online sources for news and information, so too do they direct their students to go to the Internet to do research ... Of course, the quality of that research is indeterminate (Vancouver Sun, September 2016).

The author polemically concluded the piece by proclaiming that the use of digital technology was an "unfolding tragedy" and that talk of "responsible use of social media" was "like raising kids on whiskey or cocaine and then in the midst of it prattling about how to use it responsibly."

It is important to note that the above findings did not explicitly describe "digital literacy" but rather emphasized digital technology broadly in either positive or negative ways. What we found when analyzing the data was that literacy was still largely constrained to print-based skills.

\section{Print-Based Literacy Texts to Depict Literacy}

The majority of the images that we analyzed depicted literacy activities as printbased, such as: photographs of a child sitting between her parents, all looking at a book; two young, males sitting back-to-back, each holding a picture book; mother and son sitting with a book shared between them. In total, 12 images, were collected in 2016; eight of these depicted print-based tools, such as a book or writing tools (i.e., pencil and paper), while four showed a digital tool. In 2018, seven images were collected and four contained digital tools. One of these images (an advertisement), however, showed both print and digital: a father and daughter sat side-by-side on a couch looking at a tablet. Behind them was a large bookcase full of books.

Articles that encouraged adults to limit children's screen time were paired with images of children outdoors in nature. None of the websites in the scan included images of children using digital technology. We did, however, collect seven images that contained examples of traditional print literacy- five images of book reading and two images of alphabet manipulatives (i.e., Scrabble pieces and magnetic letters).

Interestingly, in articles focused on school-related topics (e.g., curriculum reform; social inequality), the images included students of varying ages using a digital device, such as a tablet (young female) or laptop (teenaged male). Images depicting digital technology outside of school did so in a negative manner, for example, a mother sitting on a couch beside her teenage daughter, scowling while the daughter looks at her cellphone. Another notable finding was that images with digital technology mostly showed one user while images of books most often showed people reading together (i.e., adult-child). 


\section{Print-Based Books Most Valued}

Nine articles emphasized book reading in traditional print formats as the most valuable activity when describing literacy. For example, in a list of Christmas gifts, books were, 'the greatest gifts of all. Nothing comes close" (Vancouver Sun, November 2018) and that "they're wonderful to share with youngsters, especially at bedtime" (Vancouver Sun, November 2018). Other phrases included, "you can never have enough books" (Vancouver Sun, September 2016) and "Everyone is a reader, some just haven't found their favourite book yet" (Vancouver Sun, September 2016). One article offered advice on encouraging children to read and suggested, "intentionally model positive reading habits and provide time and opportunities for my older children to read ... Read physical books ... Subscribe to print newspapers and magazines" (Vancouver Sun, September 2016). To return to an article that we previously referenced, use of online resources in school-based research was given lesser value to books, negatively describing teachers who "direct their students to go to the Internet to do research" while "real books and libraries dwindle in significance in the classroom" (Vancouver Sun, September 2016).

\section{Discussion}

News media play a role in shaping the discourse around digital technology and shaping social norms. They are an important constituent of the macrosystem and its more distal, but yet important influence on young children's development and learning (Bronfenbrenner, 2005). News reports attribute general statements about the world to experts and other authorities (van Leeuwen, 2008). News media purport themselves to be neutral and as providing a space for public discourse; however, this is sometimes a fallacy (Fairclough, 1992; Wodak, 2001). Using 'the first day of school' rhetoric as an example, van Leeuwen (2008) explained that by attributing general statements to experts, news reports "not only report what the expert has said, it also, though only obliquely, counsel readers who are also parents of young children" (p. 14). Frequently, news media have focused on harms to children and spent less time highlighting the positive aspects and benefits of screen media (Livingstone \& Blum-Ross, 2020) and have often exaggerated the size of the effect or inferred causation from correlational findings (Livingstone \& Franklin, 2018). Our findings echo this: when reporting on children's engagement with digital technology, conflicting discourses were present. Digital technology was portrayed as both beneficial for children's skill development but also as a phenomenon that needs to be limited and controlled by parents and teachers. This contradiction was most notably evident during our 2016 scan that coincided with "back to school" for the Kindergarten to grade 12 school system. That negative portrayals of children's use of technology decreased over time might suggest that a more general societal acceptance of the role of digital tools in young peoples' lives is occurring.

It is noteworthy that in articles about digital technology and children that we analyzed, descriptions of "screen time" were negative. At the same time, articles described the importance of coding and encouraged the development of coding from the early years and beyond. However, an important caveat in the beneficial discourse is that this learning occurs in school settings. This rhetoric positions the authority of digital literacy development within the school and minimizes the role parents/caregivers may play in this development. In doing so, it devalues the digital activities children engage in while at home 
or in the community. This contrasts the way print-based literacy development is positioned within news publications. In those stories and images, parents/caregivers are situated in this development as important partners in learning and as crucial to children's literacy learning. Indeed, parents (and especially mothers) of young children are sometimes cast as derelict if they do not read to their children daily (e.g., Reese, 2012; Smythe, 2006).

Competing narratives create confusion and tension for parents and educators attempting to raise children in digital societies. News and media outlets have reported research suggesting prolonged exposure to screens impedes young children's development (e.g., Madigan et al., 2019), but have also reported that there is not enough evidence that shows "screen time is in itself harmful to child health at any age" (Viner et al., 2019, n.p.). This establishes conflicting discourses about the role and value of digital technology in young children's lives and parents and caregivers must decide to either follow or reject published advice. It is important to recognize the agency of parents and caregivers who encounter these messages as they are not passive recipients in their relationship to texts (Kress, 1989). However, news media's publication of contradictory reports of empirical studies can cause parental anxiety and guilt (Livingstone \& Blum-Ross, 2020). As well, negative depictions of children's digital engagement idealize a "normative vision of how (typically, middle-class) family life should look" (Livingstone \& Blum-Ross, 2020, p. 55) while simultaneously ignoring "the realities of how or why digital technologies are being incorporated into family lives" (p. 55).

We did not find a marked change in how the role of digital technology was portrayed in the two years the data were collected. However, it may be that the Covid-19 pandemic may lead to a fundamental shift as families use Zoom and similar platforms to connect with relatives who cannot be physically present and schools in some jurisdictions provide online learning. Indeed, a documentary titled "Screen time can sometimes be good for kids, says new research" televised by the Canadian Broadcasting Corporation in 2020 reflected a balanced perspective, acknowledging the affordances that digital technology offers young children and the concerns that some people have identified (Canadian Broadcasting Corporation, 2020).

We recognize the limitations of our study in the small corpus of texts analyzed from a short period of time. It is possible that a longer period of time would have resulted in more articles focused on children's engagement in digital media. However, given the mixed messages reported here, it is unlikely the findings would have been dramatically different. Despite the small nature of our study, the implications of this work are the emphasis on the impact news media can have on social discourses, which can influence attitudes towards children's digital engagement. Questions remain about how parents and educators access sources of information and which of these are privileged, and whether parents, educators and early learning practitioners are accessing the same sources. Another interesting consideration is the shift of news media from traditional print media to digital platforms. The vanishing newspaper (Meyer, 2004) has increasingly been discussed as printed newspaper subscriptions continue to drop (Loskutova, 2020). A quick Google search of 'death of print media' returned half a million results, and while the Internet hosts plenty of news, a dwindling supply of printed newspapers in a community may have lasting implications. Small, local newspapers may not have a strong online presence and their demise means less reliable, local news in communities (Heberly, 2018). As well, online- 
only news media often operate behind a paywall. Those with lower incomes may not be able to afford online subscriptions, not to mention the necessary hardware and reliable Internet connection, necessary to access news (Heberly, 2018). These questions highlight the need for more studies in this area.

As Przybylski and Weinstein (2019) argued, the "digital genie cannot be put back in the bottle" (p. 62). Rather than position children's uses of digital technology in contrasting frames-- to be limited and controlled or as positive and beneficial-- it is time to move away from 'screen time' and focus attention on quality uses of digital technology and the social nature of these practices. Indeed, Blum-Ross and Livingstone (2016) recommend moving away from the discourse of "screen time" as it is "neither a homogenous activity nor an inevitably problematic activity" (p. 27). We echo their statements and also suggest it is time to move away from clock-watching and counterproductive controlling of screen time. Instead, a more productive framing might emphasize the quality experiences and family bonding that may occur when families interact with screens together. Even Dr. Jenny Radesky, a key contributor to the American Academy of Pediatrics' (2016) policy statement, has pivoted from strict screen limits and now recommends co-use of digital technology between adults and children (e.g., Knappmeyer, 2020).

Changes in discourse shift slowly. For example, School Community Network, an organization devoted to enhancing communication between schools and families, and providing the latter with up to date knowledge, led off its January, 2021 email update with an item advertising a video called "Curriculum of the Home: Family Expectations and Supervision" (Personal Communication, School Community Network, January 13, 2021). The first of six points listed was, "Priority given to homework and reading over screen time and recreation", strongly implying that reading on screen is not valuable and that homework cannot involve digital devices. Continuing messages of risk and harm and the lack of acknowledgement of the possibilities offered by digital technology in conversations about young children are likely to remain in the foreseeable future.

\section{Acknowledgements}

This study is funded by a Social Sciences and Humanities Research Council grant \# 4352014-0525

\section{References}

American Academy of Pediatrics. (2011). Policy statement: Media use by children younger than 2 years. Pediatrics, 128(5), 1-7. http://pediatrics.aappublications.org/content/early/2011/10/12/peds.2011-1753

American Academy of Pediatrics Council on Communications and Media. (2016). Media and young minds. Pediatrics, 138(5), 1-6. https://doi.org/10.1542/peds.2016-2591

Barr, R. (2013). Memory constraints on infant learning from picture books, TV, and touchscreens. Child Development Perspectives, 7(4), 205-210. https://doi.org/10.1111/cdep.12041

Bedford, R., Saez de Urabain, I.R., Cheung, C., Karmiloff-Smith, A., \& Smith, T.J. (2016). Toddlers' fine motor milestone achievement is associated with early 
touchscreen scrolling. Frontiers in Psychology, 7, 1108.

https://doi.org/10.3389/fpsyg.2016.01108

Blum-Ross, A., \& Livingstone, S. (2016). Families and screen time: Current advice and emerging research. LSE Media Policy Project, Media Policy Brief 17. LSE. http://eprints.lse.ac.uk/66927/1/Policy\%20Brief\%2017\%20Families\%20\%20Screen\%20Time.pdf

Bronfenbrenner, U. (2005). Making human beings human: Bioecological perspectives on human development. Sage Publications.

Burnett, C. (2009). Research into literacy and technology in primary classrooms: An exploration of understandings generated by recent studies. Journal of Research in Reading,32(1), 22-37. https://doi.org/10.1111/j.1467-9817.2008.01379.x

Canadian Broadcasting Corporation. (2020). Screen time can sometimes be good for kids, says new research. https://www.cbc.ca/documentaries/the-nature-ofthings/screen-time-can-sometimes-be-good-for-kids-says-new-research1.5799251

Canadian Paediatric Society (2017). Screen time and young children: Promoting health and development in a digital world. Pediatrics \& Child Health, 22(8), 461-468. https://doi.org/10.1093/pch/pxx123

Cheung, C. (2016, December 28). What are the effects of touchscreens on toddler development? Digital Future.

https://blogs.1se.ac.uk/parenting4digitalfuture/2016/12/28/what-are-the-effects-oftouchscreens-on-toddler-development/

Cheung, C., Bedford, R., Saez de Urabain, I.R., Karmiloff-Smith, A., \& Smith, T.J. (2017). Daily touchscreen use in infants and toddlers is associated with reduced sleep and delayed sleep onset. Scientific Reports, 7(46104). http://doi.org/10.1038/srep46104

Christakis, D.A., Zimmerman, F.J., DiGiuseppe, D.L., \& McCarty, C.A. (2004). Early television exposure and subsequent attentional problems in children. Pediatrics, 113(4), 708-713. https://doi.org/10.1542/peds.113.4.708

Courage, M. (2017). Screen media and the youngest viewers: Implications for attention and learning. In F.C. Blumberg \& P.J. Brooks (Eds.), Cognitive development in digital contexts (pp. 3-28). Elsevier.

Davidson, C. (2009). Young children's engagement with digital texts and literacies in the home: Pressing matters for the teaching of English in the early years of schooling. English Teaching: Practice and Critique, 8(3), 36-54. http://education.waikato.ac.nz/research/files/etpc/files/2009v8n3art3.pdf

Dias, P., Brito, R., Ribbens, W., Daniela, L., Rubene, Z., Dreier, M., Gemo, M., Di Gioia, R., \& Chaudron, S. (2016). The role of parents in the engagement of young children with digital technologies: Exploring tensions between rights of access and protection, from 'Gatekeepers' to 'Scaffolders'. Global Studies of Childhood, 6(4), 414-427. https://doi.org/10.1177/2043610616676024

Dodge, A., Husain, N., \& Duke, N. (2011). Connected kids? K-2 children's use and understanding of the internet. Language Arts, 89(2), 86-98. https://www.jstor.org/stable/41804322 
Edwards, S. (2013). Post-industrial play: Understanding the relationship between traditional and converged forms of play in the early years. In A. Burke \& J. Marsh (Eds.), Children's virtual play worlds: Culture, learning and participation (pp. 10-26). Peter Lang.

Fairclough, N. (1995). Critical discourse analysis: The critical study of language. Routledge.

Fairclough, N. (2013). Critical discourse analysis and critical policy studies. Critical Policy Studies, 7(2), 177-197

Foucault, M. (1972) The Archaeology of knowledge (Sheridan Smith, A. M. ed.). Routledge.

Gee, E., Takeuchi, L. M., \& Wartella, E. (2018). Children and families in the digital age: Learning together in a media saturated culture. Routledge.

Gee, J. P. (2014). An introduction to discourse analysis: Theory and method (4 $\left.{ }^{\text {th }} \mathrm{ed}\right)$. Taylor and Francis Group.

Gillen J., Aliagas, C., Bar-lev, Y., Flewitt, R., Jorge, A., Kumpulainen, K., Marsh, J., Matsumoto, M., Morgade, M., Pacheco, R., Poveda, D., Sairanen, H., Sandberg, H., Scott, F., Sjöberg, U., Sundin, E., Tigane, I., \& Tomé, V. (2018). A day in the digital lives of children aged 0-3. Summary report by DigiLitEY ISCH COST Action IS1410 Working Group 1 "Digital literacy in homes and communities."

Gillespie, T. (2010). The politics of "platforms". New Media \& Society, 12(3), 347-364. https://doi.org/10.1177/1461444809342738

Hale L., \& Guan S. (2015). Screen time and sleep among school-aged children and adolescents: A systematic literature review. Sleep Medicine Reviews, 21, 50-58. https://doi.org/10.1016/j.smrv.2014.07.007

Helm, P., \& Seubert, S. (2020). Normative paradoxes of privacy: Literacy and choice in platform societies. Surveillance \& Society, 18(2), 185-198. https://ojs.library.queensu.ca/index.php/surveillance-and-society/index

Hughes, B. 2002. A playworker's taxonomy of play types (2nd ed). PlayLink.

Huh, Y.J. (2015). Making sense of gender from digital game play in three-year-old children's everyday lives: An ethnographic case study. Journal of Comparative Research in Anthropology and Sociology, 6(1), 155-170. https://www.ceeol.com/search/viewpdf?id=289518

Jäger, S. (2001). Discourse and knowledge: Theoretical and methodological aspects of a critical discourse and dispositive analysis. In R. Wodack \& M. Meyer (Eds.), Methods of critical discourse analysis (pp. 32-62). Sage. https://dx.doi.org/10.4135/9780857028020.n3

Kellner, D., \& Share, J. (2019). The critical media literacy guide: engaging media and transforming education. Brill Sense.

Kervin, L., Verenikina, I., \& Rivera, C. (2018). Digital play and learning in the home: Families' perspective. Digital Childhoods, Technologies and Children's Everyday Lives, 22, 117-130.

Knappmeyer, B. (host). (2020, July 30). The effects of screen time on the developing brain [Audio presentation]. The New York Academy of Sciences. https://www.nyas.org/ebriefings/2020/the-effects-of-screen-time-on-the- 
developing-brain/?tab=covid-

19:\%20screen\%20time\%20and\%20the\%20developing\%20brain

Kress, G. (1989). History and language: towards a social account of linguistic change. Journal of Pragmatics, 13(3), 445-66.

Kress, G., \& van Leeuwen, T. (1996). Reading images: The grammar of visual design. Routledge.

Kucirkova, N., Littleton, K., \& Kyparissiadis, A. (2018). The influence of children's gender and age on children's use of digital media at home. British Journal of Educational Technology, 49(3), 545-559. https://doi.org/10.1111/bjet.12543

Livingstone, S. (2016). Reframing media effects in terms of children's rights in the digital age. Journal of Children and Media, 10(1), 4-12.

https://doi.org/10.1080/17482798.2015.1123164

Livingstone, S., \& Blum-Ross, A. (2020). Parenting for a digital future: How hopes and fears about technology shape children's lives. Oxford University Press.

Livingstone, S., \& Franklin, K. (2018). Families with young children and 'screen time' advice. Journal of Health Visiting, 6(9), 434-439. https://doi.org/10.12968/johv.2018.6.9.434

Lupick, T (2019, April 8). Is Vancouver's Downtown Eastside still the "poorest postal code" in Canada? The Georgia Straight. https://www.straight.com/news/1225081/vancouvers-downtown-eastside-stillpoorest-postal-code-canada

Mackenzie, J. (2019). Language, gender, and parenthood online: Negotiating motherhood in Mumsnet Talk. Routledge.

Madigan, S., Browne, D., Racine, N., Mori, C., \& Tough, S. (2019). Association between screen time and children's performance on a developmental screening test. JAMA Pediatrics. 173(3), 244-250. https://doi.org/10.1001/jamapediatrics.2020.0327

Marsh, J., Hannon, P., Lewis, M. \& Ritchie, L. (2017). Young children's initiation into family literacy practices in the digital age. Journal of Early Childhood Research, 15 (1), 47-60. https://doi.org/10.1177/1476718X15582095

Marsh, J., Plowman, L., Yamada-Rice, D., Bishop, J., \& Scott, F. (2016). Digital play: a new classification. Early Years, 36(3), 242-253. https://doi.org/10.1080/09575146.2016.1167675

Marsh, J., Plowman, L., Yamada-Rice, D., Bishop, J., Lahmar, J., Scott, F., Davenport, A., Davis, A., French, S., Piras, K., Thornhill, M., Robinson, S., \& Winter, P. (2015). Exploring play and creativity in preschoolers' use of apps: Final project report. www.techandplay.org

McLuhan, M. (1964). Understanding media: The extension of man. McGraw-Hill.

McPake, J., Plowman, L., \& Stephen, C. (2013). Pre-school children creating and communicating with digital technologies in the home. British Journal of Educational Technology, 44(3), 421-431. https://doi.org/10.1111/j.14678535.2012.01323.X

Meyer, M. (2001). Between theory, method, and politics: Positioning of the approaches to CDA. In R. Wodak \& M. Meyer (Eds.), Methods of critical discourse analysis (pp. 14- 31). Sage. https://dx.doi.org/10.4135/9780857028020.n2 
Miller, C.J., Marks, D.J., Miller, S.R., Berwid, O.G., Kera, E.C., Santra, A., \& Halperin, J.M. (2007). Brief report: Television viewing and risk for attention problems in preschool children. Journal of Pediatric Psychology, 32(4), 448-452. https://doi.org/10.1093/jpepsy/js1035

Nichols, T.P., \& LeBlanc, R.J. (2020). Beyond apps: Digital literacies in a platform society. The Reading Teacher, 74(1), 103-109. http://doi.org/10.1002/trtr.1926

O'Hara, M. (2011). Young children's ICT experiences in the home: Some parental perspectives. Journal of Early Childhood Research, 9(3), 220-231. https://doi.org/10.1177/1476718X10389145

Orben, A. (2020). Teenagers, screens and social media: A narrative review of reviews and key studies. Social Psychiatry and Psychiatric Epidemiology, 55, 407-414. https://doi.org/10.1007/s00127-019-01825-4

Ozturk, G., \& Ohi, S. (2019). What do they do digitally? Identifying the home digital literacy practices of young children in Turkey. Early Years. https://doi.org/10.1080/09575146.2019.1702925

Plowman, L., \& McPake, J. (2013). Seven myths about young children and technology. Childhood Education, 89(1), 27-33. https://doi.org/10.1080/00094056.2013.757490

Plowman, L., McPake, J., \& Stephen, C. (2008). Just picking it up? Young children learning with technology at home. Cambridge Journal of Education, 38(3), 303319. https://doi.org/10.1080/03057640802287564

Przybylski, A., \& Weinstein, N. (2019). Digital screen time limits and young children's psychological well-being: Evidence from a population-based study. Child Development, 90(1), 56-65. http://doi.org/10.1111/cdev.13007

Radesky, J., \& Zuckerman, B. (2017). Learning from apps in the home: Parents and play. In N. Kucirkova and G. Falloon (Eds). Apps, technology and young learners: International evidence for teaching (pp. 14-26). Routledge.

Razfar, A., \& Yang, E. (2010). Digital, hybrid, and multilingual literacies in early childhood. Language Arts, 88(2), 114- 124.

Reese, E. (2012). The tyranny of shared book reading. In S. Suggate (Ed.), Contemporary issues in childhood education and development (pp. 59-68). Routledge.

Schlembach, S., \& Johnson, M.L. (2014). Parents' beliefs, attitudes and behaviors concerning their young children's screen media use. Dialog, 17(2), 95-104.

Shapiro, J. (2018). The new childhood: Raising kids to thrive in a connected world. Little, Brown Spark.

Smythe, S. (2006). The good mother: A critical discourse analysis of literacy advice to mothers in the twentieth century (Unpublished doctoral dissertation). University of British Columbia, Vancouver, Canada.

Srnicek, N. (2017). Platform capitalism. Polity.

Strouse, G.A., \& Ganea, P.A. (2017). Parent-toddler behavior and language differ when reading electronic and print picture books. Frontiers in Psychology, 8. https://doi.org/10.3389/fpsyg.2017.00677

Stephen, C., McPake, J., Plowman, L., \& Berch-Heyman, S. (2008). Learning from the children: Exploring preschool children's encounters with ICT at home. Journal of 
Early Childhood Research, 6(2) 99-117.

https://doi.org/10.1177/1476718X08088673

Stephen, C., Stevenson, O. \& Adey, C. (2013). Young children engaging with technologies at home: The influence of family context. Journal of Early Childhood Research, 11 (2), 149-164. https://doi.org/10.1177/1476718X12466215

Teichert, L. (2014). 21st century vision using a 20th century curriculum: Examining British Columbia's Kindergarten Curriculum Package. Canadian Children, 39(3), 34-41.

Teichert, L. (2017). To digital or not to digital: How mothers are navigating the digital world with their young children. Language \& Literacy: A Canadian Education EJournal, 19(1), 63-76. https://doi.org/10.20360/G22P5W

Teichert, L. (2018). An examination of young children's digital literacy practices in the home before and during the transition to kindergarten (Unpublished doctoral dissertation). University of British Columbia, Vancouver, Canada.

Teichert, L. (2020). Negotiating screen time: A mother's struggle of 'no screen time' with her infant son. Journal of Early Childhood Literacy, 20(3), 524-550. https://doi.org/10.1177/1468798420926623

Teichert, L., \& Anderson, A. (2014). 'I don't even know what blogging is': The role of digital media in a five-year old girl's life. Early Child Development and Care, 184(11), 1677-1691. https://doi.org/10.1080/03004430.2013.875540

van Dijk, J. (2000). The digital divide. Polity Press.

van Dijck, J., Poell, T., \& de Waal, M. (2018). The platform society: Public values in a connective world. Oxford University Press

Vertovec, S. (2021). Super-diversity: Migration and social complexity. Routledge.

Viner, R., Davie, M., \& Firth, A. (2019). The health impacts of screen time: a guide for clinicians and parents. Royal College of Paediatrics and Child Health. Available at: https://www.rcpch.ac.uk/sites/default/files/2018-

12/rcpch_screen_time_guide_-_final.pdf

Vittrup, B., Snider, S., Rose, K., \& Rippy, J. (2014). Parental perceptions of the role of media and technology in their young children's lives. Journal of Early Childhood Research, 14(1), 43-54. https://doi.org/10.1177/1476718X14523749

Vygotsky, L. (1978). Mind in society: The development of higher psychological processes. Harvard University Press.

Wodak, R. (2001). What CDA is about: A summary of its history, important concepts and its developments. In R. Wodak \& M. Meyer (Eds.), Methods of critical discourse analysis (pp. 1- 13). Sage. https://dx.doi.org/10.4135/9780857028020.n1

Wohlwend, K. (2009). Early adopters: Playing new literacies and pretending new technologies in print-centric classrooms. Journal of Early Childhood Literacy, 9(2), 117-140. https://doi.org/10.1177/1468798409105583

Wohlwend, K. (2013). Literacy playshop: New literacies, popular media, and play in the early childhood classroom. Teachers College Press.

Wohlwend, K. (2017). Toddlers and touchscreens: Learning "Concepts Beyond Print" with tablet technologies. In R. J. Meyer \& K. F. Whitmore (Eds.), Reclaiming 
early literacy: Narratives of hope, power, and vision (pp. 64-74). Lawrence Erlbaum.

Wohlwend, K., Vander Zanden, S., Husbye, N.E., \& Kuby, C.R. (2011). Navigating discourses in place in the world of Webkinz. Journal of Early Childhood Literacy, 11(2), 141-163. http://doi.org/10.1177/1468798411401862

Wong, S. (2015). Mobile digital devices and preschoolers' home multiliteracy practices. Language and Literacy, 17(2), 75-90. https://doi.org/10.20360/G2CP49 World Health Organization. (2019). WHO guidelines on physical activity, sedentary behavior and sleep for children under 5 years of age. World Health Organization.

\section{Author Biographies}

Laura Teichert is an Assistant Professor in the Department of Special Education and Literacy Studies at Western Michigan University. Her research interests focus on young children's early digital literacy in home, school, and community contexts; pre-service teacher education in literacy; and family literacy. Previously, she has worked as an early literacy specialist and an elementary school teacher.

Ann Anderson is a Professor in the Department of Curriculum and Pedagogy at the University of British Columbia. Her research and teaching foci include mathematics education in the early years, parent mediation of young children's multi-literacies at home, and family literacy. Ann researches the ways in which young children's multi-literacies are supported in families from diverse backgrounds, prior to and during primary school and has ongoing collaborations with colleagues in family literacy.

Jim Anderson is Professor Emeritus (June, 2020) in the Department of Language and Literacy Education at the University of British Columbia. Prior to joining UBC, he worked in the public education system as a classroom teacher, reading specialist, language arts coordinator and assistant superintendent of curriculum and instruction. His research and teaching focus on early literacy and family literacy, particularly on issues around social inequality.

Jan Hare is an Anishinaabe scholar and educator from the M'Chigeeng First Nation in northern Ontario, Canada. She is a Professor in Language and Literacy Education and a Canada Research Chair in Indigenous Pedagogy in the Faculty of Education at the University of British Columbia. Her teaching and research focus on improving educational outcomes for Indigenous learners and centering Indigenous knowledge systems in early learning, K-12 schooling, and post-secondary education.

Marianne McTavish is Professor of Teaching and Associate Dean of Teacher Education in the Faculty of Education at the University of British Columbia. She teaches introductory language arts courses to pre-service teachers and graduate courses in literacy. Her research work with early childhood teacher candidates and digital literacies reconceptualizes the way literacy is taught and practiced. She has authored several professional resources in addition to scholarly articles on young children's emergent literacy learning, teacher education, and family literacy. 